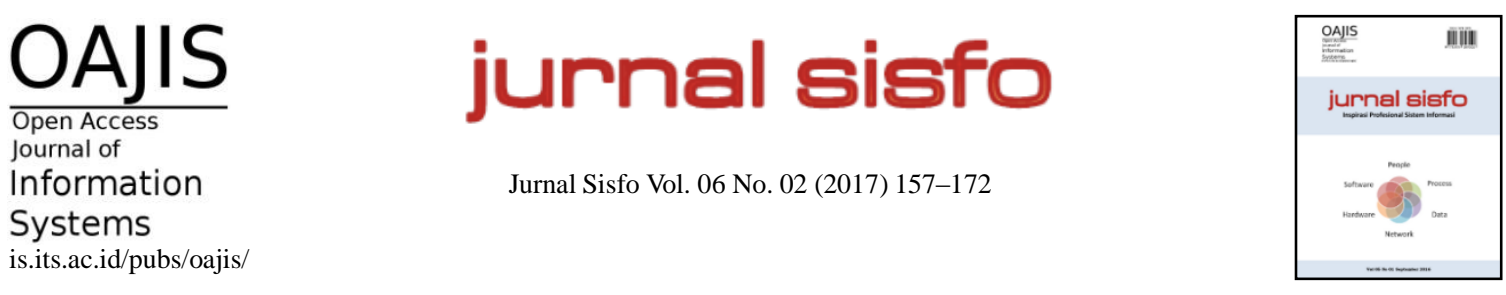

\title{
Prediksi Nilai Mata Kuliah Mahasiswa Menggunakan Algoritma K-Apriori
}

\author{
Lailil Muflikhah ${ }^{*}$, W. Lisa Yunita, M. Tanzil Furqon \\ Fakultas Ilmu Komputer, Universitas Brawijaya
}

\begin{abstract}
The main purpose of grade-course prediction is to help students to take elective courses corectly. The most students taking the course is based on the number of students taking the course. A set of student's academic transcript can be analyzed for the patterns of association (association rule) between their subjects and grades. K-Apriori is one of data mining methods to find the patterns of their association rule to purpose for prediction of the other grade-course. The main step of this method is to cluster the data using K-Means and to get the pattern for the subjects and their grade using Apriori algorithm. How ever, there are missing values due to all offered courses are not taken by each students. Therefore, it is implemented preprocessing data using Wiener Transformation before it is applied to Apriori algorithm to find their pattern. The testing is based on student's academic transcript using minimum support and confidence as $10 \%$ with lift ratio > 1 . As a result, the generated rule from low and high GPA are achieved of error rate $8.75 \%$ and $8.5 \%$. How ever, the generated rule from average GPA is achieved of error rate $11 \%$.
\end{abstract}

Keywords: K-Apriori, Prediction, Association rule, Wiener Transformation, GPA

\begin{abstract}
Abstrak
Tujuan utama dari prediksi nilai mata kuliah adalah membantu mahasiswa mengambil mata kuliah pilihan secara tepat. Kebanyakan mahasiswa mengambil mata kuliah didasarkan pada jumlah mahasiswa mengambil matakuliah. Sekumpulan transkrip mahasiswa dapat dianalisis pola keterkaitan (association rule) antar nilai matakuliah. K-Apriori merupakan metode data mining untuk mencari pola keterkaitan nilai mata kuliah sehingga dapat digunakan memprediksi nilai mata kuliah lain. Tahapan utama metode ini meliputi mengelompokkan data menggunakan metode K-Means dan menemukan pola nilai mata kuliah menggunakan Apriori. Namun terdapat kekosongan nilai karena seluruh mata kuliah yang ditawarkan tidak diambil setiap mahasiswa. Oleh karenanya, dilakukan preprocessing data menggunakan Wiener Transformation sebelum dicari polanya.Pengujian didasarkan tingkat kemampuan akademik mahsiswa dengan minimum support dan confidence sebesar $10 \%$ dan lift ratio $>1$. Hasilnya, rule yang dibangkitkan dari IPK di bawah dan di atas rata-rata memiliki tingkat kesalahan sebesar $8.75 \%$ dan $8.5 \%$. Sedangkan jika rule dibangkitkan dari IPK rata-rata memiliki kesalahan sebesar $11 \%$.
\end{abstract}

Kata kunci: K-Apriori, Prediksi, Association Rule, Wiener Transformation, IPK

(C) 2017 Jurnal SISFO.

Histori Artikel : Disubmit 8 September 2016; Diterima 14 November 2016; Tersedia online 18 Januari 2017

${ }^{*}$ Corresponding Author

Email address: laililmf@email.com (Lailil Muflikhah) 


\section{Pendahuluan}

Seringkali mahasiswa mengalami kebingungan dalam mengambil mata kuliah pilihan, yang mana tidak didasarkan pada kemampuan prestasi yang dimiliki namun berdasarkan pada jumlah mahasiswa yang mengambil mata kuliah tersebut. Selain itu, minimnya pengetahuan mengenai muatan mata kuliah tersebut menyebabkan mahasiswa kurang tepat dalam menentukan pilihan. Pengambilan mata kuliah pilihan berkaitan dengan mata kuliah prasyarat dan keminatan dari setiap mahasiswa sehingga membutuhkan arahan dari pembimbing akademik. Namun, keterbatasan waktu yang dimiliki dosen pembimbing menjadi pertimbangan untuk membuat suatu sistem yang dapat memprediksi nilai matakuliah yang akan diambil sesuai dengan potensi yang dimiliki oleh mahasiswa tersebut. Untuk membantu mahasiswa dalam permasalahan di atas, diperlukan sistem pendukung keputusan rekomendasi penentuan matakuliah pilihan [1]. Sistem ini dibangun menggunakan data nilai mahasiswa terdahulu untuk memprediksi nilai matakuliah yang terbaik dengan menggunakan metode Apriori, namun masih diperlukan pencarian rule yang terbaik dengan memasukkan nilai minimum support dan minimum confidence secara manual.

K-Apiori merupakan salah satu dari metode dalam data mining untuk mencari keterkaitan antar data berdasarkan karakteristiknya sehingga terbentuk rule dengan berbasis pada cluster. Metode ini merupakan pengembangan dan perbaikan dari algoritma Apriori dimana dihasilkan rule yang lebih sederhana. Pada metode ini dilakukan penggabungan metode clustering, yakni K-Means dan algoritma Apriori melalui tahapan preprocessing untuk pembersihan data menggunakan Wiener Transformation. Adapun beberapa penelitian terdahulu yang mendukung makalah ini adalah penelitian mengenai "Web Log Mining using $K$ Apriori Algorithm" [2], "Frequent Itemset Mining of Market Basket Data using K-Apriori Algorithm" [3] dan "Aplikasi Association Rule Untuk Menemukan Pola Pada Data Mahasiswa Matematika ITS” [4].

Sehingga pada penelitian ini digunakan algoritma $K$-Apriori untuk memprediksi nilai matakuliah pilihan keminatan yang akan diambil mahasiswa berdasarkan nilai matakuliah wajib yang telah diambil. Lebih lanjut dilakukan analisis terhadap besarnya tingkat kesesuaian rule yang dihasilkan beserta performansi dari metode $K$-Apriori.

\section{Tinjauan Pustaka}

Beberapa penelitian sebelumya yang terkait penelitian menggunakan algoritma $K$-Apriori untuk mengolah data menjadi informasi dalam sebuah supermarket untuk mengolah data barang yang berjudul Frequent Itemset Mining of Basket Data Using K-Apriori Algorithm [2]. Pada tahapan preprocessing, dilakukan pengisian kekosongan nilai dengan metode Wiener Transformation terhadap data dalam Supermarket. Sistem akan melakukan penghitungan K-Means dari nilai Wiener Transformation yang telah didapatkan. Setelah didapatkan cluster yang sesuai dengan sesuai dengan data yang dimasukkan kemudian dilakukan perhitungan Apriori untuk mencari pola data barang yang dimasukkan oleh user. Sehingga dihasilkan barang yang direkomendasikan sesuai dengan kebiasaan transaksi customer.

Adapun penelitian lain yang terkait dengan metode yang sama berjudul Web Log Mining Using K-Apriori Algorithm [3]. Penelitian ini ditujukan untuk mencari relevansi data dari user dengan data dari World Wide $W e b(W W W)$. Selain itu juga terdapat penelitian dengan topik aplikasi Association Rule Mining untuk menemukan pola pada data mata kuiah beserta nilai mahasiswa Matematika ITS [4].

\subsection{Data Mining}

Perolehan informasi berasal dari penggalian data yang berjumlah besar agar bermanfaat disebut dengan data mining. Pemanfaatan data mining terdiri dari beberapa proses penggabungan untuk mendapatkan sebuah informasi. Sehingga data mining dapat dikatakan sebagai bagian dari proses Knowledge Dicovery in Database (KDD). Terdapat beberapa tahapan penting data mining yaitu [5][6] : 


\section{1) Data Cleaning}

Data yang berasal dari database memiliki banyak noise sehingga dibutuhkan pembersihan data.

2) Data Integration

Setelah mendapatkan data relevan dan konsisten, dilakukan penggabungan data.

3) Data Selection

Data yang telah digabungkan dipilih yang paling relevan untuk analisis. Proses ini dilakukan penyimpanan menggunakan database, sehingga proses analisis bertumpu pada data selection.

4) Data Transformation

Kelanjutan dari data selection, dimana data yang ada diubah untuk mencari data pattern dari sebuah database. Proses ini akan sangat penting untuk mengetahui pola data dari informasi yang akan dicari.

5) Pattern Evaluation

Evaluasi dilakukan untuk mengetahui pola yang telah terbentuk telah sesuai dengan knowledge. Pattern evaluation juga melakukan pengecekan terhadap perhitungan pencarian pola data.

6) Knowledge Presentation

Tahap ini merupakan tahap akhir untuk mendapatkan hasil secara visual ditunjukkan ke user.

\subsection{Association Rule}

Association rule dapat diartikan sebagai teknik untuk melakukan pencarian hubungan antar item pada sebuah dataset. Hubungan yang didapatkan antar item berasal dari kombinasi yang terbentuk untuk membuat sebuah rule. Pembentukan association rule adalah tahap untuk proses akhir data mining dalam mengetahui pola data pada sebuah dataset [7].

\subsubsection{Apriori}

Apriori merupakan salah satu teknik data mining dengan mengolah informasi ke dalam bentuk itemset berdasarkan jumlah kemunculan data sehingga didapatkan association rule. Secara garis besar terdapat dua tahapan yaitu dengan penggabungan (join) dan pemangkasan (prune) [8]. Dalam algoritma ini diperlukan beberapa kondisi yang dipenuhi yaitu minimum support, confidence lift ratio dan benchmark. Support merupakan banyaknya itemset yang muncul secara bersamaan dalam sebuah transaksi sehingga disebut juga support count sebagaimana dinyatakan dalam persamaan 1 [9]. Sedangkan untuk pembentukan itemset dengan 2 kombinasi ditunjukkan pada persamaan 2 [7]:

Support $(A)=\frac{\text { Jumlah transaksi yang mengandung } A}{\text { Total transaksi }}$

Support $(A, C)=P(A \cap C)$

$$
=\frac{\text { Jumlah transaksi yang mengandung A dan C }}{\text { Total transaksi }}
$$

Penentuan nilai minimum support digunakan sebagai nilai acuan untuk menentukan batas minimum itemset yang menyatakan kelayakan dari association rule yang terbentuk. Itemset yang tidak layak akan dilakukan pemangkasan, sedangkan itemset yang layak akan dilakukan penggabungan [10]. Setelah terbentuk rule, dicari nilai confidence sebagaimana ditunjukkan dalam persamaan 3 dan 4 [7]. Nilai minimum confidence digunakan sebagai parameter untuk menentukan batas terendah tingkat kepercayaan sebuah rule terhadap asosiasi yang telah dibentuk [6].

Confidence $(A \rightarrow B)=P(B \mid A)$ 
$P(B \mid A)=\frac{\text { Jumlah transaksi yang mengandung } A \text { dan } B}{\text { Jumlah transaksi yang mengandung } A}$

Rule yang berasal dari assosiasi confidence digunakan sebagai dasar pengambilan keputusan. Dasar pengambilan keputusan ditentukan dengan nilai lift ratio $>1$ [7]. Kejadian yang ada dalam sebuah rule diperoleh secara acak dari antecedent dan consequence. Nilai lift ratio dapat dinyatakan pada persamaan 5 dan 6. Item yang memiliki nilai lift ratio $<1$, dapat dinyatakan tidak ada asosiasi yang kuat antara antecedent dengan consequent [7].

$$
\begin{aligned}
\text { Lift Ratio } & =\frac{\text { confidence }}{\text { expected confidence }} \\
\text { Lift Ratio } & =\frac{\operatorname{Pr}(A \mid C)}{\operatorname{Pr}(C)}
\end{aligned}
$$

\subsection{K-Means}

Dalam data mining, clustering adalah salah satu teknik yang digunakan untuk mengelompokkan data dalam sebuah data set. Metode ini, mengelompokkan data sesuai dengan jumlah cluster berdasarkan nilai rata-rata jarak terdekat sehingga dihasilkan pengelompokan dengan tingkat kemiripan tertinggi [11]. Langkah-langkah clustering K-Means dengan penghitungan kedekatan jarak dari seluruh pasangan data serta menentukan ketepatan data dalam clustering yang telah terbentuk berdasarkan kedekatan jarak yang salah satunya menggunakan Manhattan Distance sebagaimana dalam persamaan 7 [12]:

$d(x, y)=\sum\left\|x_{i}-y_{i}\right\|$

dimana $x=$ dataset dari matriks baris $x_{1}, x_{2}, \ldots \ldots x_{m}$ dan $y=$ dataset dari matriks kolom $y_{1}, y_{2}, \ldots \ldots . y_{m}$.

\subsection{K-Apriori}

Algoritma $K$-Apriori memiliki dua algoritma utama yang digunakan yaitu K-Means dan Apriori. Namun sebelum melakukan perhitungan menggunakan kedua algoritma tersebut harus melakukan tahapan preprocessing data dengan menggunakan Wiener Transformation. Kemudian dilakukan penghitungan dengan algoritma $K$-Means untuk mencari data dengan tingkat kemiripan tertinggi. Setelah mendapatkan kemiripan, dilakukan proses pencarian rule menggunakan algoritma Apriori.

Tahap preprocessing pada K-Apriori dilakukan dengan memasukkan data pada matriks $p$ (baris) $\times q$ (kolom). Pendekatan perhitungan Wiener Transformation dibantu dengan perhitungan mean $(\mu)$ dan varian $\left(\sigma^{2}\right)$. Mean dan varian dihitung dari input $X$, yaitu data mentah yang dibersihkan. Perhitungan mean dan varian sebagaimana dalam persamaan 8 dan 9 yang telah ada mean $(\mu)[2]$ :

$\mu=\frac{1}{p q} \sum_{n_{1} n_{2} \in n} X\left(n_{1}, n_{2}\right)$

dimana: $\mu=$ rata-rata nilai per kolom input; $p=$ baris input; $q=$ kolom input; $n_{1}=$ data ke- $1 ; n=$ data ke- $n ; X$ $=$ input matriks 2 dimensi.

Sedangkan persamaan 9 merupakan perhitungan varian $\left(\sigma^{2}\right)[2]$ :

$\sigma^{2}=\frac{1}{p q} \sum_{n_{1} n_{2} \in n}\left(X^{2}\left(n_{1}, n_{2}\right)-\mu\right)$ 
dimana: $\sigma^{2}=$ varian; $p=$ baris input; $q=$ kolom input; $n_{1}=$ data ke- $1 ; n=$ data ke- $n ; X^{2}=$ kuadrat input matriks dua dimensi; $\mu=$ rata-rata nilai per kolom input.

Nilai varian pada pesamaan 10 merupakan perhitungan dari matriks $X$ terhadap nilai $p$ (baris) dan $q$ (kolom) kemudian dikurangi matriks mean 1 x $q$ (kolom). Lebih lanjut dituliskan pada persamaan 10 untuk mendapatkan $Y\left(n_{1}, n_{2}\right)$ sebagai luaran dari metode Wiener Transformation [2] :

$Y\left(n_{1}, n_{2}\right)=\mu+\frac{\sigma^{2}-v^{2}}{\sigma^{2}}\left(X\left(n_{1}, n_{2}\right)-\mu\right)$

dimana: $\sigma^{2}=$ varian; $v^{2}=$ rata-rata nilai hasil varian; $n_{1}=$ data ke- $1 ; n=$ data ke-n; $X^{2}=$ kuadrat input matriks dua dimensi; $\mu=$ rata-rata nilai per kolom input; $Y=$ output matriks 2 dimensi. Sedangkan untuk mendapatkan nilai dari $v^{2}$ didasarkan pada persamaan 11 [2]:

$v^{2}=\frac{\sigma^{2}}{\sum \sigma^{2}}$

\section{Metodologi}

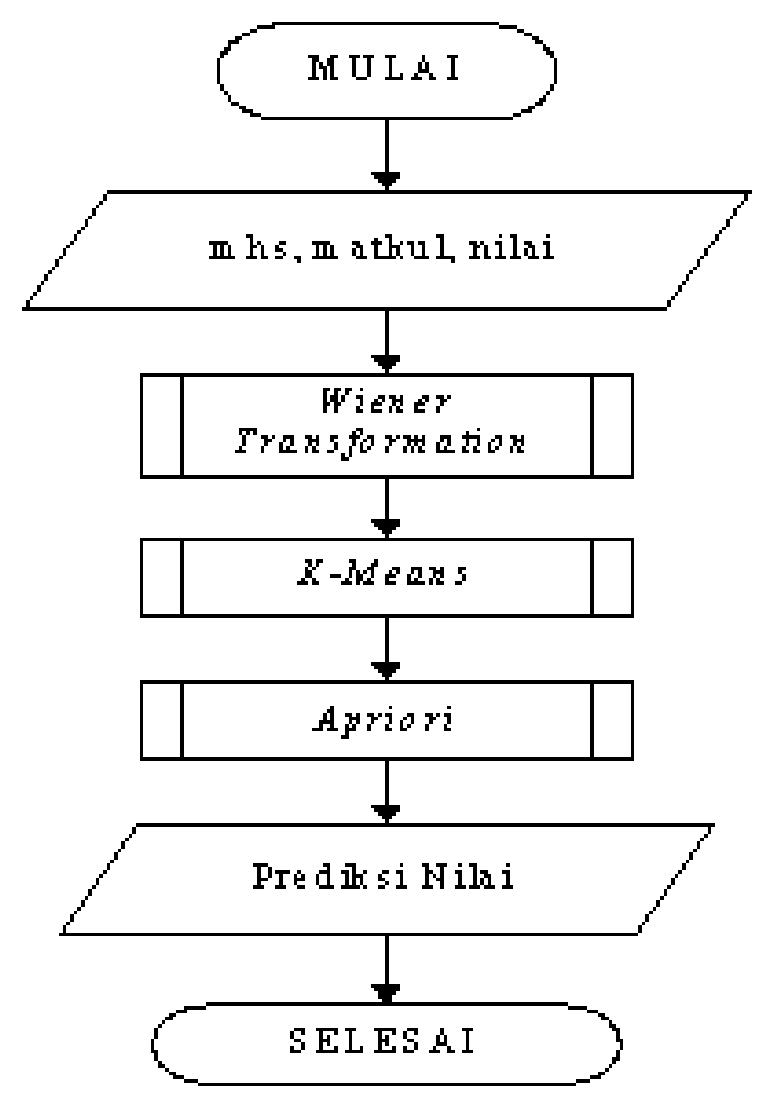

Gambar 1 Gambaran Umum Prediksi Nilai Matakuliah Menggunakan K-Apriori

Metode yang digunakan dalam penelitian ini adalah $K$-Apriori sebagaimana ditunjukkan dalam gambaran umum sistem pada Gambar 1. Beberapa parameter masukan meliputi nama dan NIM mahasiswa, matakuliah beserta nilainya, minimum support, dan minimum confidence. Sebagai langkah awal dilakukan preprocessing mengunakan Wiener Transformation untuk menghilangkan noise (kekosongan nilai) pada 
data. Nilai $Y$ sebagai luaran dari Wiener Transformation digunakan untuk proses clustering yang mana digunakan $K$-means terhadap empat bidang minat. Data training yang digunakan sebagai data input diproses menggunakan association rule untuk dicari frequent itemset tertinggi. Pencarian frequent itemset dilakukan dengan menghitung support count pada setiap rule yang terbentuk. Sedangkan nilai confidence digunakan untuk pencarian rule yang memenuhi nilai kepercayaan dari rule yang terbentuk. Nilai lift ratio digunakan untuk mengetahui kekuatan rule terhadap data yang digunakan. Rule yang telah terbentuk dilakukan pencocokan terhadap input data sehingga prediksi nilai mata kuliah diperoleh berdasarkan rule yang terbentuk dengan mempertimbangkan nilai yang diinputkan.

\subsection{Preprocessing Data}

Adapun tahapan preprocessing dalam rangka penghilangan missing value dengan Wiener Transformation adalah sebagai berikut :

1) Dilakukan penghitungan nilai mean $(\mu)$ dari data krs mahasiswa ke dalam matriks $1 \times q$ (Id mahasiswa) dari data konversi nilai ke dalam bentuk angka.

2) Dilakukan penghitungan nilai varian $\left(\sigma^{2}\right)$ dari data ke dalam matriks $1 \times q$ (Id mahasiswa).

3) Dilakukan penghitungan rata-rata varian $\left(\sigma^{2}\right)$ ke dalam matriks skalar.

4) $Y\left(n_{1}, n_{2}\right)$ merupakan hasil perhitungan mean dan varian yang telah didapatkan dalam bentuk matriks $p$ (mata kuliah) $\times q($ Id mahasiswa $)$

\subsection{Proses Clustering dengan K-means}

Setelah preprocessing data, dilakukan clustering terhadap hasil dari Wiener Transformation. Prediksi nilai mata kuliah pilihan berdasarkan empat keminatan sehingga menjadikan adanya empat cluster. Adapun empat keminatan yang ada di Fakultas Ilmu Komputer pada Program studi Informatika Universitas Brawijaya meliputi: 1. Rekayasa Perangkat Lunak; 2. Pengembang Sistem Cerdas; 3. Perancangan dan Pengembangan Game; 4. Perekayasa Jaringan Komputer (Computer Network Engineer). Lebih lanjut penghitungan $K$-means untuk melakukan clustering data berdasarkan tingkat kemiripannya dengan mengacu pada persamaan 2 sebagaimana berikut:

1) Pengambilan data dari wiener transformation

2) Clustering terhadap data wiener transformation secara random

3) Perhitungan jumlah nilai data sesuai cluster yang terbentuk.

4) Penghitungan nilai centroid setiap data menggunakan penghitungan Manhattan Distance.

5) Pencarian nilai minimum dari cluster $\left\|x_{i}-z_{j}\right\|$.

6) Penentuan cluster baru.

7) Perbandingan hasil penjumlahan $\left\|x_{i}-z_{j} \leq x_{i}-z_{t}\right\|$. Jika $j \neq t$ maka kembali ke langkah 4 hingga dicapai $j=t$.

\subsection{Proses Association Rule Apriori}

Setelah didapatkan data transaksi, maka dilakukan pencarian pola aturan menggunakan Apriori. Pembentukan itemset dilakukan dengan menggabungkan mata kuliah dengan nilai yang ada pada setiap transaksi yang ada. Sedangkan nomor transaksi menggunakan nomor mahasiswa yang masuk dalam cluster yang sama dengan data input.

Proses Apriori dilakukan dengan melakukan pembuatan large itemset yang akan digunakan untuk mendapatkan rule. Rule yang didapat nantinya merupakan hasil dari kombinasi itemset yang akan dibandingkan dengan kesesuaian data item data input. Pembentukan rule akhir berdasarkan nilai minimum 
support dan minimum confidence yang telah diinputkan oleh user. Pencarian pola aturan menggunakan Apriori sebagai berikut:

1) Dilakukan pengambilan data dari konversi, wiener transformation, $k$-means dan data transaksi.

2) Pembentukan Large-1 itemset, jika terdapat kemunculan Large-1 itemset, maka dilanjutkan ke Langkah 3. Jika itemset tidak ditemukan, maka akan dilakukan pemangkasan (prune).

3) Pembandingan frequent itemset dengan nilai minimum support pada Large-1 itemset.

4) Pembandingan frequent itemset dengan nilai minimum confidence pada Large-1 itemset.

5) Penghitungan nilai lift ratio untuk mengetahui kekuatan rule. Jika lift ratio kurang dari 1 maka akan dilakukan pemangkasan (prune).

6) Penyimpanan database rule yang memiliki kesamaan dengan input data.

7) Pembentukan Large- $n+1$ itemset dan diulangi langkah 2-6 dengan ketentuan Large- $n+1$ itemset setiap rule yang baru terbentuk.

Data itemset yang memenuhi minimum support dipilih untuk pembentukan rule. Nilai minimum confidence digunakan untuk mengetahui data yang memiliki kekuatan terhadap rule tertinggi. Penghitungan lift ratio dilakukan untuk menguji lemah atau tidaknya sebuah rule yang telah terseleksi dalam tahap confidence. Jika sebuah rule memiliki nilai lift ratio kurang dari 1, maka rule tersebut kurang baik untuk digunakan sebagai pengambilan keputusan. Pengambilan keputusan hanya didasarkan dari nilai lift ratio $\geq 1$ yang digunakan untuk melakukan pengecekan terhadap input data. Jika rule yang terbentuk memiliki kesamaan dengan input data, maka rule akan disimpan dalam database. Penyimpanan rule akan digunakan sebagai pertimbangan untuk melakukan prediksi nilai mata kuliah.

\subsection{Contoh Permasalahan}

Misalkan diberikan data set dari KRS mahasiswa PTIIK angkatan 2008-2011 yang telah lulus. Pada data training mencakup keseluruhan nilai baik mata kuliah wajib maupun pilihan. Namun pada data uji hanya digunakan data mata kuliah wajib sebagaimana ditunjukkan pada Tabel 1.

Tabel 1. Data set mahasiswa beserta nilai matakuliah

\begin{tabular}{|c|c|c|c|c|c|c|c|c|c|c|c|c|}
\hline \multirow{2}{*}{$\begin{array}{c}\text { Kel } \\
\text { MatKul }\end{array}$} & \multirow{2}{*}{$\begin{array}{l}\text { Mata } \\
\text { kuliah }\end{array}$} & \multicolumn{11}{|c|}{ Nilai } \\
\hline & & Nur & Hadi & Dwi & Putra & Mila & Widi & Said & Anisa & Dimas & Zainuri & Nita \\
\hline $\mathbf{S}$ & DatMin & $\mathrm{B}+$ & - & A & A & $\mathrm{sB}+$ & B & A & D & A & $\mathrm{C}+$ & $\mathrm{C}+$ \\
\hline $\mathbf{i}$ & PCD & B & - & $\mathrm{B}+$ & A & A & A & $\mathrm{B}+$ & - & A & - & $\mathrm{B}+$ \\
\hline $\mathbf{s}$ & SisPak & $\mathrm{B}+$ & - & A & A & A & A & $\mathrm{B}+$ & - & A & - & - \\
\hline C & SPK & A & - & A & A & A & A & A & A & A & - & - \\
\hline e & STKI & A & - & - & - & - & $\mathrm{B}+$ & - & - & B & - & - \\
\hline $\mathbf{r}$ & LogFuz & B & - & A & - & B & - & $\mathrm{B}+$ & $\mathrm{C}+$ & $\mathrm{B}+$ & - & A \\
\hline d & PemTeks & - & - & - & - & - & - & - & - & - & - & - \\
\hline $\mathbf{a}$ & JST & $\mathrm{C}+$ & - & $\mathrm{B}+$ & $\mathrm{B}+$ & $\mathrm{B}+$ & B & A & - & B & - & - \\
\hline \multirow[t]{2}{*}{$\mathbf{s}$} & Alev & B & - & A & A & A & B & B & - & $\mathrm{B}+$ & - & - \\
\hline & MPPL & D+ & - & - & - & $\mathrm{B}+$ & - & B & A & - & B & - \\
\hline $\mathbf{R}$ & PPP & - & - & - & - & - & - & - & - & - & - & - \\
\hline $\mathbf{P}$ & PBPU & - & - & - & - & - & - & - & - & - & - & - \\
\hline $\mathbf{L}$ & PAPB & $\mathrm{B}+$ & A & $\mathrm{A}$ & - & - & - & - & - & - & A & - \\
\hline
\end{tabular}




\begin{tabular}{|c|c|c|c|c|c|c|c|c|c|c|c|c|}
\hline \multirow{2}{*}{$\begin{array}{c}\text { Kel } \\
\text { MatKul }\end{array}$} & \multirow{2}{*}{$\begin{array}{l}\text { Mata } \\
\text { kuliah }\end{array}$} & \multicolumn{11}{|c|}{ Nilai } \\
\hline & & Nur & Hadi & Dwi & Putra & Mila & Widi & Said & Anisa & Dimas & Zainuri & Nita \\
\hline & PPL & - & B & - & - & - & - & $\mathrm{C}+$ & - & - & - & - \\
\hline & $\mathrm{ABD}$ & $\mathrm{C}+$ & - & $\mathrm{B}+$ & $\mathrm{C}+$ & - & - & - & - & $\mathrm{B}+$ & B & $\mathrm{C}+$ \\
\hline & BDT & - & $\mathrm{C}$ & - & - & - & - & - & - & B & B & - \\
\hline & ERP & $\mathrm{B}+$ & - & $\mathrm{B}+$ & A & A & B & A & - & $\mathrm{B}+$ & - & - \\
\hline & GamePro & - & - & A & A & A & - & - & - & - & - & - \\
\hline & MR & - & A & A & A & A & - & - & A & - & - & - \\
\hline G & ProgGame & - & - & - & - & - & - & - & - & - & - & - \\
\hline $\mathbf{a}$ & Penggame & - & - & - & - & - & - & - & - & $\mathrm{C}+$ & - & - \\
\hline $\mathbf{m}$ & PerGame & - & B & - & - & - & - & - & - & - & $\mathrm{B}+$ & - \\
\hline \multirow[t]{5}{*}{ e } & GameAI & - & - & - & - & - & $\mathrm{B}+$ & - & - & - & - & - \\
\hline & ProgGraf3D & - & - & - & - & - & - & - & - & - & - & - \\
\hline & PK3d & - & - & - & - & - & - & - & - & - & - & - \\
\hline & PMGame & - & - & - & - & - & - & - & - & - & - & - \\
\hline & AJT & - & A & - & A & - & - & A & - & - & A & - \\
\hline $\mathbf{J}$ & Jarmul & - & B & - & - & - & - & - & - & - & B & - \\
\hline $\mathbf{a}$ & JarLan & - & A & - & - & - & - & - & - & - & B & - \\
\hline $\mathbf{r}$ & PAJ & - & $\mathrm{B}+$ & - & - & - & - & - & & - & - & - \\
\hline $\mathbf{K}$ & Sister & - & A & - & - & - & - & - & B & - & A & - \\
\hline o & ProgJar & - & - & - & - & - & - & - & - & - & A & - \\
\hline \multirow[t]{4}{*}{$\mathbf{m}$} & AdSer & - & A & - & - & - & - & - & - & - & A & - \\
\hline & Jarnil & - & A & - & - & - & - & - & - & - & - & - \\
\hline & BasDat & $\mathrm{B}+$ & A & A & B & B & $\mathrm{B}+$ & $\mathrm{B}+$ & $\mathrm{C}+$ & $\mathrm{B}+$ & A & B \\
\hline & $\mathrm{KC}$ & $\mathrm{B}+$ & $\mathrm{C}+$ & A & B & $\mathrm{B}+$ & B & B & $\mathrm{C}+$ & $\mathrm{B}+$ & B & B \\
\hline $\mathbf{W}$ & MatKom & A & B & A & A & A & $\mathrm{B}+$ & A & B & A & $\mathrm{B}+$ & B \\
\hline $\mathbf{a}$ & MatKomLan & B & $\mathrm{B}+$ & A & B & $\mathrm{B}+$ & B & A & $\mathrm{D}+$ & $\mathrm{C}+$ & $\mathrm{C}+$ & B \\
\hline $\mathbf{j}$ & $\mathrm{PBO}$ & $\mathrm{B}+$ & B & B & $\mathrm{B}+$ & B & B & $\mathrm{C}+$ & B & A & B & $\mathrm{B}+$ \\
\hline $\mathbf{i}$ & GrafKom & $\mathrm{B}+$ & B & $\mathrm{B}+$ & $\mathrm{B}+$ & $\mathrm{B}+$ & B & A & B & $\mathrm{B}+$ & $\mathrm{C}+$ & B \\
\hline \multirow[t]{4}{*}{ b } & IMK & B & $\mathrm{B}+$ & B & A & A & $\mathrm{B}+$ & $\mathrm{B}+$ & B & B & $\mathrm{B}+$ & B \\
\hline & Jarkom & B & $\mathrm{B}+$ & $\mathrm{C}+$ & $\mathrm{B}+$ & B & B & A & $\mathrm{C}+$ & $\mathrm{B}+$ & B & $\mathrm{C}+$ \\
\hline & RPL & $\mathrm{B}+$ & $\mathrm{B}+$ & $\mathrm{B}+$ & A & $\mathrm{B}+$ & $\mathrm{C}+$ & B & $\mathrm{B}+$ & $\mathrm{B}+$ & $\mathrm{B}+$ & B \\
\hline & ASD & $\mathrm{C}+$ & $\mathrm{C}+$ & B & B & B & $\mathrm{C}+$ & B & $\mathrm{C}$ & B & $\mathrm{B}+$ & $\mathrm{C}+$ \\
\hline
\end{tabular}

\subsubsection{Preprocessing Data}

Pada Tabel 1, terlihat nilai dalam bentuk huruf sehingga dilakukan konversi ke dalam bentuk angka $(\mathrm{A}=4$; $\mathrm{B}+=3.5 ; \mathrm{B}=3 ; \mathrm{C}+=2.5 ; \mathrm{C}=2 ; \mathrm{D}=1 ; \mathrm{E}=0$ ). Namun terdapat kekosongan nilai pada beberapa mata kuliah 
pilihan maka diperlukan transformasi nilai mahasiswa secara keseluruhan dengan menggunakan metode Wiener Transformation sebagaimana ditunjukkan dalam contoh berikut:

1) Menghitung Mean

Misalkan dilakukan penghitungan mean dilakukan terhadap 11 data, 10 data merupakan data training dan 1 data testing. Perhitungan mean dilakukan pada matriks $X i$ (vector $X$ (baris) terhadap kolom). $\mu=\frac{1}{11} *\left(\sum V\left[3.5_{1}+0_{2}+4_{3}+\cdots+0_{11}\right]\right)=2.68$

Tabel 2. Menghitung mean

\begin{tabular}{cccccccccccccc}
\hline Mata kuliah & Nur & Hadi & Dwi & Putra & Mila & Widi & Said & Anisa & Dimas & Zainuri & Nita & $\boldsymbol{\mu}$ \\
\hline DatMin & 3.5 & 0 & 4 & 4 & 3.5 & 3 & 4 & 1 & 4 & 2.5 & 0 & $\mathbf{2 . 6 8}$ \\
\hline
\end{tabular}

2) Menghitung Varian

Nilai mean digunakan untuk mencari nilai varian. Dimana varian membutuhkan nilai kuadrat $X i$ dan nilai $\mu i$ pada setiap kolom. Penghitungan varian dilakukan terhadap 11 data, 10 data merupakan data training dan 1 data testing. $\sigma^{2}=\frac{1}{11} *\left(\left(\sum V\left[\left((3.5)^{2}-2.68_{1}\right)+\cdots+\left((2.5)^{2}-2.77_{26}\right)\right]\right)=6.84\right.$

Tabel 3. Menghitung Varian

\begin{tabular}{ccccccccccccc}
\hline Mata kuliah & Nur & Hadi & Dwi & Putra & Mila & Widi & Said & Anisa & Dimas & Zainuri & Nita & $\boldsymbol{\sigma}^{\mathbf{2}}$ \\
\hline DatMin & 9.57 & -2.68 & 13.32 & 13.32 & 9.57 & 6.32 & 13.32 & -1.68 & 13.32 & 3.57 & -2.68 & $\mathbf{6 . 8 4}$ \\
\hline
\end{tabular}

3) Mencari Nilai $Y\left(n_{1}, n_{2}\right)$

Nilai $Y\left(n_{1}, n_{2}\right)$ diperoleh dari rata-rata varian pada setiap matriks skalar per mata kuliah. Hasil seluruh varian dijumlahkan dan dibagi dengan jumlah kolom sebesar jumlah matakuliah yakni 44.

$v^{2}=\frac{1}{44} *\left(\left(\sum V\left[6.84_{1}+6.50_{2}+7.05_{3}+\cdots+5.07_{44}\right]\right)=3.74\right.$

Penghitungan $Y\left(n_{1}, n_{2}\right)$ didapatkan nilai $1 \times q$ di setiap matriks $X i$ terhadap jumlah baris $(n)$.

$Y(n 1, n 2)=2.68_{1}+\frac{6.84_{1}-3.74_{1}}{6.84_{1}} *\left(3.5_{1,1}-2.68_{1}\right)=3.05$

Tabel 4. Nilai $Y$

\begin{tabular}{ccccccccccccc}
\hline \multirow{2}{*}{ Mata kuliah } & Nur & Hadi & Dwi & Putra & Mila & Widi & Said & Anisa & Dimas & Zainuri & Nita \\
\hline DatMin & 3.05 & 1.47 & 3.28 & 3.28 & 3.05 & 2.83 & 3.28 & 1.92 & 3.28 & 2.60 & 1.47 \\
\hline
\end{tabular}

Sehingga hasil transformasi secara keseluruhan ditunjukkan pada Tabel 5.

Tabel 5. Nilai matakuliah bidang minat Sistem Cerdas menggunakan Wiener Transformation

\begin{tabular}{cccccccccccc}
\hline & & \multicolumn{10}{c}{ Sistem Cerdas } \\
\cline { 3 - 11 } & Nama & DatMin & PCD & SisPak & SPK & STKI & LogFuz & PemTeks & JST & Alev \\
\hline 1 & Nur & 3.05 & 2.63 & 2.94 & 3.53 & 0.69 & 1.88 & 0.00 & 2.19 & 2.49 \\
2 & Hadi & 1.47 & 1.36 & 1.30 & 1.25 & 1.47 & 1.61 & 0.00 & 1.59 & 1.46
\end{tabular}




\begin{tabular}{ccccccccccc}
\hline \multirow{2}{*}{ No } & Nama & \multicolumn{7}{c}{ Sistem Cerdas } \\
\cline { 3 - 11 } & & DatMin & PCD & SisPak & SPK & STKI & LogFuz & PemTeks & JST & Alev \\
\hline 3 & Dwi & 3.28 & 2.85 & 3.18 & 3.53 & 1.47 & 1.97 & 0.00 & 2.43 & 2.84 \\
4 & Putra & 3.28 & 3.06 & 3.18 & 3.53 & 1.47 & 1.61 & 0.00 & 2.43 & 2.84 \\
5 & Mila & 3.05 & 3.06 & 3.18 & 3.53 & 1.47 & 1.88 & 0.00 & 2.43 & 2.84 \\
6 & Widi & 2.83 & 3.06 & 3.18 & 3.53 & 0.42 & 1.61 & 0.00 & 2.31 & 2.49 \\
7 & Said & 3.28 & 2.85 & 2.94 & 3.53 & 1.47 & 1.93 & 0.00 & 2.54 & 2.49 \\
8 & Anisa & 1.92 & 1.36 & 1.30 & 3.53 & 1.47 & 1.84 & 0.00 & 1.59 & 1.46 \\
9 & Dimas & 3.28 & 3.06 & 3.18 & 3.53 & 0.15 & 1.93 & 0.00 & 2.31 & 2.66 \\
10 & Zainuri & 2.60 & 1.36 & 1.30 & 1.25 & 1.47 & 1.61 & 0.00 & 1.59 & 1.46 \\
11 & Nita & 1.47 & 1.36 & 1.30 & 1.25 & 1.47 & 1.61 & 0.00 & 1.59 & 1.46 \\
\hline
\end{tabular}

\subsubsection{Proses Clustering dengan K-Means}

Kemudian dilakukan pengelompokan berdasarkan empat bidang keminatan menggunakan metode $K$-Mean clustering dan sebagai ilustrasi ditunjukkan dalam Tabel 6.

Tabel 6. Cluster Data Informasi Akademik Mahasiswa

\begin{tabular}{|c|c|c|c|c|c|}
\hline \multirow{2}{*}{ No } & \multirow{2}{*}{ Nama } & \multicolumn{4}{|c|}{ Cluster Data } \\
\hline & & K1 & K2 & K3 & K4 \\
\hline 1 & Nur & $*$ & & & \\
\hline 2 & Hadi & & & & $*$ \\
\hline 3 & Dwi & $*$ & & & \\
\hline 4 & Putra & & $*$ & & \\
\hline 5 & Mila & & & $*$ & \\
\hline 6 & Widi & $*$ & & & \\
\hline 7 & Said & & $*$ & & \\
\hline 8 & Anisa & & & $*$ & \\
\hline 9 & Dimas & & $*$ & & \\
\hline 10 & Zainuri & & & & $*$ \\
\hline 11 & Nita & * & & & \\
\hline
\end{tabular}

\subsubsection{Proses Association Rule menggunakan algoritma Apriori}

Selanjutnya dilakukan pembentuknn rule menggunakan algoritma Apriori. Adapun data yang digunakan memiliki kesamaan cluster dengan data uji misalkan data ke-11 untuk dilakukan pencarian pola prediksi. Pada awalnya terbentuk Large-1 itemset dengan threshold misalkan dengan memberikan minimum support $=30 \%$ dan minimum confidence $=50 \%$. 


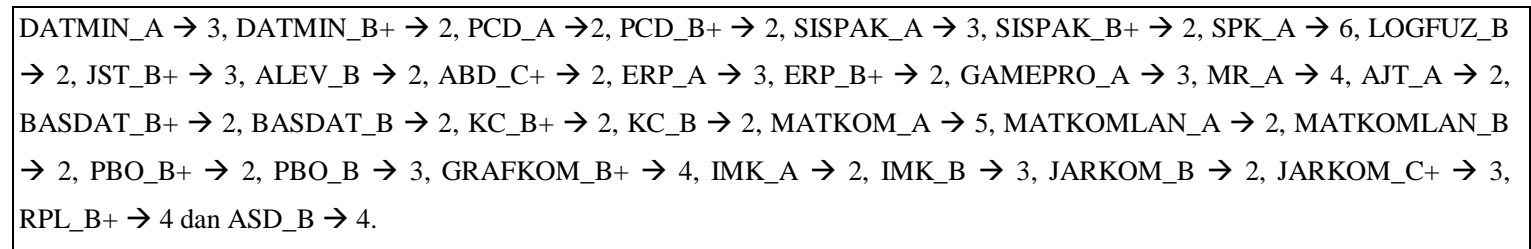

Gambar 4 Rule dari Pembentukan Large-1 itemset

Pada Gambar 4 terlihat sejumlah itemset yang memenuhi minimum support, kemudian dilakukan kombinasi 2 itemset. Pada penggabungan itemset yaitu DATMIN_B+ dan SPK_A dengan nilai support $\{$ DATMIN_B $\rightarrow$ SPK_A $\}=\frac{3}{6} \times 100 \%=50 \%$, sedangkan nilai confidence sebesar $\frac{3}{3} \times 100 \%=100 \%$; Itemset yang memenuhi threshold minimum support dan minimum confidence dapat dinyatakan sebagai rule. Untuk mendapatkan nilai lift ratio, dilakukan penghitungan benchmark confidence untuk menentukan nilai probabilitas terhadap rule yang terbentuk. Adapun benchmark confidence [DATMIN_B+ $\rightarrow$ SPK_A $\}=\frac{6}{6}=1.00$ dan nilai lift ratio $=\frac{\frac{2}{2}}{\frac{6}{6}}=\frac{1}{1}=1.00$. Sehingga secara keseluruhan dari pembentukan Large-2 itemset dihasilkan sebagaimana Gambar 5 dan rule yang terpilih dapat dituliskan hasil prediksi dari matakuliah beserta nilainya seperti pada Tabel 7.

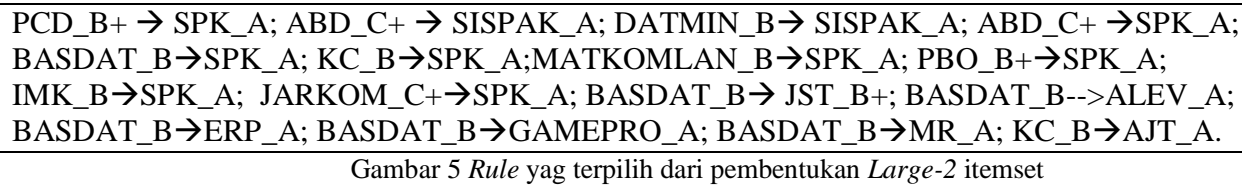

Tabel 7. Mata Kuliah beserta Prediksi Nilai

\begin{tabular}{cc}
\hline Matkul & Nilai \\
\hline SPK & A \\
SISPAK & A \\
JST & B+ \\
ALEV & A \\
ERP & A \\
GAMEPRO & A \\
MR & A \\
AJT & A \\
\hline
\end{tabular}

\section{Hasil dan Pembahasan}

Skenario pengujian dilakukan untuk mengetahui pengaruh dari rule yang terbentuk dari sekelompok data berdasarkan tingkat kemampuan mahasiswa yakni tingkat kemampuan rata-rata, tingkat kemampuan diatas rata-rata dan tingkat kemampuan dibawah rata-rata. Adapun data masukan berupa data mahasiswa dengan mata kuliah wajib beserta nilainya dengan nilai minimum support $=10 \%$ dan minimum confidence $=10 \%$ dengan lift ratio $>1$ yang digunakan dalam menentukan prediksi mata kuliah pilihan beserta nilainya berdasarkan tingkat kemampuan akademik yang dimiliki. 


\subsection{Tingkat Kemampuan Mahasiswa Rata-Rata}

Hasil prediksi dari rule memiliki beberapa bagian, yaitu jumlah nilai error dengan 7 data yang masuk pada cluster yang sama dengan input data user. Kondisi yang digunakan dalam melakukan pengujian yaitu pada minsup dan mincof sebesar 10\%. Tabel 8 adalah hasil prediksi yang diberikan sistem dibandingkan dengan data riil.

Tabel 8. Prediksi Mata kuliah beserta Nilai pada Tingkat Kemampuan Mahasiswa Rata-Rata

\begin{tabular}{|c|c|c|c|}
\hline No & Data Rïl & Data Prediksi & Selisih (Error) \\
\hline 1 & Arsitektur Jaringan Terkini=>- & Arsitektur Jaringan Terkini=>B & - \\
\hline 2 & Jaringan Multimedia=>- & Jaringan Multimedia $=>A$ & - \\
\hline 3 & $\begin{array}{c}\text { Perancangan dan Analisa Jaringan } \\
\text { Komputer=>- }\end{array}$ & $\begin{array}{c}\text { Perancangan dan Analisa Jaringan } \\
\text { Komputer=>B }\end{array}$ & - \\
\hline 4 & Sistem Terdistribusi=>- & Sistem Terdistribusi $=>B$ & - \\
\hline 5 & Jaringan Nirkabel=>- & Jaringan Nirkabel $=>A$ & - \\
\hline 6 & $\begin{array}{c}\text { Pengembangan Aplikasi Perangkat } \\
\text { Bergerak=>B+}\end{array}$ & $\begin{array}{c}\text { Pengembangan Aplikasi Perangkat } \\
\text { Bergerak=>B }\end{array}$ & $|3.5-3|=0.5$ \\
\hline 7 & Administrasi Basis Data $=>C+$ & Administrasi Basis Data $=>A$ & $|2.5-4|=1.5$ \\
\hline 8 & Basis Data Terdistribusi=>- & Basis Data Terdistribusi $=>B+$ & - \\
\hline 9 & $E R P=>A$ & $\mathrm{ERP}=>\mathrm{A}$ & $|0-0|=0$ \\
\hline 10 & $\begin{array}{l}\text { Perancangan Sumberdaya } \\
\text { Perusahaan }(E R P)=>A\end{array}$ & $\begin{array}{l}\text { Perancangan Sumberdaya } \\
\text { Perusahaan }=>C\end{array}$ & $|4-2|=2$ \\
\hline 11 & Game $\mathrm{AI}=>-$ & Game $\mathrm{AI}=>\mathrm{B}+$ & - \\
\hline 12 & Logika Fuzzy=>A & Logika Fuzzy=>B+ & $|4-3.5|=0.5$ \\
\hline 13 & Administrasi Basis Data $=>C+$ & Administrasi Basis Data $=>B$ & $|2.5-3|=0.5$ \\
\hline 14 & $\begin{array}{l}\text { Perencanaan Sumberdaya } \\
\text { Perusahaan }(E R P)=>A\end{array}$ & $\begin{array}{l}\text { Perencanaan Sumberdaya } \\
\text { Perusahaan=>B }\end{array}$ & $|4-3|=1$ \\
\hline 15 & Pola-Pola Perancangan=>- & Pola-Pola Perancangan $=>B$ & - \\
\hline 16 & $\begin{array}{c}\text { Pengembangan Aplikasi Perangkat } \\
\text { Bergerak }=>\mathrm{B}+\end{array}$ & $\begin{array}{c}\text { Pengembangan Aplikasi Perangkat } \\
\text { Bergerak=>A }\end{array}$ & $|3.5-4|=0.5$ \\
\hline 17 & Administrasi Basis Data $=>C+$ & Administrasi Basis Data=>B+ & $|2.5-3.5|=1$ \\
\hline
\end{tabular}

Dari hasil prediksi, didapatkan selisih nilai error terhadap data yaitu, $\frac{\frac{0.5+1.5+2+0.5+0.5+1+0.5+1}{17}}{4}=$ $\frac{0.44}{4} x 100 \%=11 \%$, dimana nilai seluruh selisih dijumlahkan dan dibagi rentang nilai tertinggi yaitu 4 . Nilai 4 digunakan karena rentang nilai tertinggi dimiliki oleh nilai A.

\subsection{Tingkat Kemampuan Mahasiswa diatas Rata-rata}

Hasil prediksi dari rule memiliki beberapa bagian yaitu jumlah nilai error dengan 5 data yang masuk pada cluster yang sama dengan user. Kondisi yang digunakan untuk melakukan pengujian yaitu pada minsup dan mincof sebesar 10\% yang ditunjukkan pada Tabel 9.

Dari hasil pemberian prediksi mata kuliah beserta nilainya, didapatkan selisih nilai error terhadap data 
yaitu, $\frac{\frac{0.5+0.5+1+0.5+1+1+1.5+0.5+0.5+0.5}{19}}{4}=\frac{0.34}{4} \times 100 \%=8.5 \%$, dimana nilai seluruh selisih dijumlahkan dan dibagi rentang nilai tertinggi yaitu 4. Nilai 4 digunakan karena rentang nilai tertinggi dimiliki oleh nilai A.

Tabel 9. Prediksi Mata kuliah beserta Nilai pada Tingkat Kemampuan Mahasiswa Diatas rata-rata

\begin{tabular}{|c|c|c|c|}
\hline No & Data Riil & Data Prediksi & Selisih (Error) \\
\hline 1 & Jaringan Multimedia=>- & Jaringan Multimedia $=>A$ & - \\
\hline 2 & Pemrograman Jaringan=>- & Pemrograman Jaringan $=>B$ & - \\
\hline 3 & Jaringan Nirkabel=>- & Jaringan Nirkabel $=>A$ & - \\
\hline 4 & Sistem pakar $=>B+$ & Sistem pakar $=>B$ & $|3.5-3|=0.5$ \\
\hline 5 & Sistem Temu Kembali Informasi=>B+ & $\begin{array}{l}\text { Sistem Temu Kembali } \\
\text { Informasi=>A }\end{array}$ & $|3.5-4|=0.5$ \\
\hline 6 & Sistem Temu Kembali Informasi=>B+ & $\begin{array}{l}\text { Sistem Temu Kembali } \\
\text { Informasi }=>B+\end{array}$ & $|0-0|=0$ \\
\hline 7 & Logika Fuzzy=>A & Logika Fuzzy=>A & $|0-0|=0$ \\
\hline 8 & $\begin{array}{l}\text { Perencanaan Sumberdaya } \\
\text { Perusahaan }(E R P)=>A\end{array}$ & $\begin{array}{l}\text { Perencanaan Sumberdaya } \\
\text { Perusahaan }(E R P)=>A\end{array}$ & $|0-0|=0$ \\
\hline 9 & Logika Fuzzy=>A & Logika Fuzzy=>B & $|4-3|=1$ \\
\hline 10 & $\begin{array}{c}\text { Pengembangan Aplikasi Perangkat } \\
\text { Bergerak }=>B+\end{array}$ & $\begin{array}{c}\text { Pengembangan Aplikasi Perangkat } \\
\text { Bergerak=>B }\end{array}$ & $|3.5-3|=0.5$ \\
\hline 11 & Administrasi Basis Data $=>C+$ & Administrasi Basis Data=>B+ & $|2.5-3.5|=1$ \\
\hline 12 & Basis Data Terdistribusi=>- & Basis Data Terdistribusi=>B+ & - \\
\hline 13 & $\begin{array}{l}\text { Perencanaan Sumberdaya } \\
\text { Perusahaan }(E R P)=>A\end{array}$ & $\begin{array}{l}\text { Perencanaan Sumberdaya } \\
\text { Perusahaan }(E R P)=>B\end{array}$ & $|4-3|=1$ \\
\hline 14 & Sistem Pakar $=>B+$ & Sistem Pakar $=>B+$ & $|0-0|=0$ \\
\hline 15 & Administrasi Basis Data $=>C+$ & Administrasi Basis Data $=>A$ & $|2.5-4|=1.5$ \\
\hline 16 & Logika Fuzzy=>A & Logika Fuzzy=>B+ & $|4-3.5|=0.5$ \\
\hline 17 & Basis Data Terdistribusi=>- & Basis Data Terdistribusi $=>A$ & - \\
\hline 18 & $\begin{array}{l}\text { Perencanaan Sumberdaya } \\
\text { Perusahaan }(E R P)=>A\end{array}$ & $\begin{array}{l}\text { Perencanaan Sumberdaya } \\
\text { Perusahaan }(E R P)=>B+\end{array}$ & $|4-3.5|=0.5$ \\
\hline 19 & Administrasi Basis Data $=>C+$ & Administrasi Basis Data $=>B$ & $|2.5-3|=0.5$ \\
\hline
\end{tabular}

\subsection{Tingkat Kemampuan Mahasiswa dibawah Rata-rata}

Hasil prediksi dari rule memiliki beberapa bagian, yaitu jumlah nilai error dengan 5 data yang masuk pada cluster yang sama dengan user. Kondisi yang digunakan untuk melakukan pengujian yaitu pada minsup dan mincof sebesar 10\%, yang ditunjukkan pada Tabel 10.

Tabel 10. Prediksi Mata kuliah beserta Nilai pada Tingkat Kemampuan Mahasiswa Dibawah rata-rata

\begin{tabular}{cccc}
\hline No & Data Riil & Data Prediksi & Selisih $($ Error $)$ \\
\hline 1 & Arsitektur Jaringan Terkini=>- & Arsitektur Jaringan Terkini=>B & - \\
2 & Jaringan Multimedia=>- & Jaringan Multimedia=>B & - \\
3 & Jaringan Komputer Lanjut=>- & Jaringan Komputer Lanjut=>C+ & - \\
\hline
\end{tabular}




\begin{tabular}{|c|c|c|c|}
\hline No & Data Riil & Data Prediksi & Selisih (Error) \\
\hline 4 & Sistem Terdistribusi=>- & Sistem Terdistribusi $=>A$ & - \\
\hline 5 & Pemrograman Jaringan $=>-$ & Pemrograman Jaringan $=>B+$ & - \\
\hline 6 & Pengolahan Citra Digital=>B+ & Pengolahan Citra Digital=>B+ & $|0-0|=0$ \\
\hline 7 & Logika Fuzzy=>A & Logika Fuzzy=>B & $|4-3|=1$ \\
\hline 8 & Logika Fuzzy=>A & Logika Fuzzy $=>C+$ & $|4-2.5|=1.5$ \\
\hline 9 & $\begin{array}{c}\text { Managemen Proyek Perangkat } \\
\text { Lunak }=>C+\end{array}$ & $\begin{array}{c}\text { Managemen Proyek Perangkat } \\
\text { Lunak=>B }\end{array}$ & $|2.5-3|=0.5$ \\
\hline 10 & Perancangan dan Analisa Jarkom=>- & $\begin{array}{l}\text { Perancangan dan Analisa } \\
\text { Jarkom }=>B\end{array}$ & - \\
\hline 11 & Jaringan Nirkabel=>- & Jaringan Nirkabel=>B & - \\
\hline 12 & $\begin{array}{c}\text { Pengembangan Apikasi Perangkat } \\
\text { Bergerak }=>B+\end{array}$ & $\begin{array}{l}\text { Pengembangan Apikasi } \\
\text { Perangkat Bergerak }=>A\end{array}$ & $|3.5-4|=0.5$ \\
\hline 13 & Administrasi Basis Data $=>C+$ & Administrasi Basis Data $=>D$ & $|2.5-2|=0.5$ \\
\hline 14 & Pemrograman Game=>- & Pemrograman Game $=>B$ & - \\
\hline 15 & Administrasi Basis Data $=>C+$ & Administrasi Basis Data=>B+ & $|2.5-3.5|=1$ \\
\hline 16 & $\begin{array}{l}\text { Perencanaan Sumberdaya } \\
\text { Perusahaan }(E R P)=>A\end{array}$ & $\begin{array}{c}\text { Perencanaan Sumbersaya } \\
\text { Perusahaan=>B }\end{array}$ & $|4-3|=1$ \\
\hline 17 & Perancangan dan Analisa Jarkom=>- & $\begin{array}{c}\text { Perancangan dan Analisa } \\
\text { Jarkom }=>\mathrm{B}+\end{array}$ & - \\
\hline 18 & Sistem Terdistribusi=>- & Sistem Terdistribusi $=>C+$ & - \\
\hline 19 & Jaringan Nirkabel=>- & Jaringan Nirkabel=>B+ & - \\
\hline 20 & Administrasi Basis Data $=>C+$ & Administrasi Basis Data=>C+ & $|0-0|=0$ \\
\hline 21 & $\begin{array}{l}\text { Perencangan Sumberdaya } \\
\text { Perusahaan=>A }\end{array}$ & $\begin{array}{l}\text { Perencangan Sumberdaya } \\
\text { Perusahaan=>C }\end{array}$ & $|4-2|=2$ \\
\hline 22 & Perancangan dan Analisa Jarkom=>- & $\begin{array}{c}\text { Perancangan dan Analisa } \\
\text { Jarkom }=>\mathrm{C}+\end{array}$ & - \\
\hline 23 & Jaringan Nirkabel=>- & Jaringan Nirkabel=>A & - \\
\hline
\end{tabular}

Dari hasil prediksi mata kuliah beserta nilainya, didapatkan selisih nilai error terhadap data yaitu, $\frac{\frac{1+1.5+0.5+0.5+0.5+1+1+2}{23}}{4}=\frac{0.35}{4}=8.75 \%$, dimana nilai seluruh selisih dijumlahkan dan dibagi rentang nilai tertinggi yaitu 4 . Nilai 4 digunakan karena rentang nilai tertinggi dimiliki oleh nilai A.

Sehingga untuk mengetahui manfaat rule atau ketepatan dalam prediksi mata kuliah beserta nilainya maka diukur tingkat kesalahan dari hasil pengujian tersebut sebagaimana ditunjukkan dalam Tabel 11.

Tabel 11. Perbandingan Tingkat Kesalahan berdasarkan Kemampuan Prestasi Mahasiswa

\begin{tabular}{ccc}
\hline No & Jenis Pengujian & Error rate \\
\hline 1 & Kemampuan IP Rata-Rata & $11 \%$ \\
2 & Kemampuan IP Tinggi & $8.75 \%$ \\
3 & Kemampuan IP Rendah & $8.5 \%$ \\
\hline
\end{tabular}


Untuk mengetahui performansi dari metode yang digunakan dalam penelitian ini dilakukan penghitungan waktu komputasi dari algoritma K-Apriori yang terdiri dari tiga metode: preprocessing (Wiener Transformation), Clustering (K-Means) dan pencarian rule (Apriori). Metode terakhir membutuhkan waktu eksekusi yang lebih lama karena memiliki proses penghitungan kemunculan dari sejumlah kombinasi dan pencarian untuk prediksi nilai dari matakuliah yang akan diambil dari database. Waktu komputasi yang dibutuhkan masing-masing metode berdasarkan tingkat kemampuan akademik mahasiswa dalam pengujian sebagaimana ditunjukkan pada Tabel 12, Tabel 13 dan Tabel 14.

Tabel 12. Waktu yang diperlukan pada data dengan tingkat Kemampuan Mahasiswa rata-rata

\begin{tabular}{ccc}
\hline Metode & Waktu dalam second & Keterangan \\
\hline Wiener Transformation & 1.0239 & 3 iterasi \\
K-means & 3.3591 & 17 rule (prediksi) \\
Apriori & 88.2564 & \\
Keseluruhan Metode (K-Apriori) & 92.6394 & Keterangan \\
\hline & & - \\
Tabel 13. Waktu yang diperlukan pada data dengan tingkat Kemampuan Mahasiswa Diatas rata-rata \\
\hline Metode & Waktu dalam second & 3 iterasi \\
\hline Wiener Transformation & 1.1185 & 19 rule (prediksi) \\
K-means & 3.4144 & - \\
Apriori & 45.4113 & 49.9442 \\
\hline
\end{tabular}

Tabel 14. Waktu yang diperlukan pada data dengan Tingkat Kemampuan Mahasiswa Dibawah rata-rata

\begin{tabular}{ccc}
\hline Metode & Waktu dalam second & Keterangan \\
\hline Wiener Transformation & 1.8841 & 3 iterasi \\
K-means & 3.3100 & 9 rule (prediksi) \\
Apriori & 61.5269 & \\
Keseluruhan Metode (K-Apriori) & 66.721 & \\
\hline
\end{tabular}

\section{Kesimpulan}

\subsection{Simpulan}

Berdasarkan penelitian yang telah dilakukan, maka dapat ditarik beberapa kesimpuan sebagai berikut:

1) Metode $K$-Apriori dapat digunakan memprediksi nilai mata kuliah pilihan yang akan diambil sesuai dengan keminatan mahasiswa dengan memberikan minimum confidence dan minimum support.

2) Tingkat kemanfaatan dari rule yang dihasilkan terlihat berdasarkan dari error rate yang dihasilkan, Prediksi nilai matakuliah dapat digunakan dari pembangkitan rule terhadap mahasiswa yang memiliki IPK rendah ataupun tinggi. Hal ini ditunjukkan nilai error rate yang dihasilkan paling rendah dibandingkan mahasiswa yang memiliki IPK rata-rata.

3) Adapun waktu yang diperlukan paling tinggi dalam metode K-Apriori adalah pada tahapan pembentukan rule dengan menggunakan algoritma Apriori. 


\subsection{Saran}

Berdasarkan penelitian yang dilakukan, penulis membutuhkan beberapa hal untuk pengembangan ke masa yang akan datang, yaitu :

1) Adanya hasil prediksi matakuliah yang akan diambil dengan mempertimbangkan nilai mata kuliah prasyaratnya sehingga sesuai dengan masukan yang dikehendaki user.

2) Oleh karena besarnya waktu yang diperlukan pada tahapan pembentukan rule, maka disarankan untuk menggunakan algoritma yang lain.

\section{Daftar Rujukan}

[1] Dharmayanti, Dian. 2014, "Model Sistem Pendukung Keputusan Dalam Penentuan Mata Kuliah Pilihan di Jurusan Teknik Informatika Unikom.

[2] D ,Kurmar Ashok ., M.C, Annie Loraine Charlet. 2011. Frequent Itemset Mining of Market Basket Data using K-Apriori Algorithm. Departement Computer Science Government Arts College. Trichy. Tamil Nadu. India

[3] D ,Kurmar Ashok ., M.C, Annie Loraine Charlet. 2012. Web Log Mining using K-Apriori Algorithm. Departement Computer Science Government Arts College. Trichy. India. India.

[4] Virgiawan, Donny Mitra., Mukhlash, Imam. 2013. "Aplikasi Association Rule Untuk Menemukan Pola Pada Data Mahasiswa Matematika ITS”. Matematika, Fakultas Matematika dan Ilmu Pengetahuan Alam, Institut Teknologi Sepuluh Nopember. Surabaya.

[5] Zins, Chaim. 2007. Conceptual Aprroaches for Defining Data, Information and Knowledge. Journal of the American Society for Information Science and Technology, 58(4):479-493, 2007. Israel.

[6] Fadly, Ari. 2011. Konsep Data Mining. Komunitas eLearning IlmuKomputer.Com Copyright (C) 2003-2011 IlmuKomputer.Com.

[7] Ikhsan, Muhammad ST,. M.Kom., Dahria, Muhammad, SE., M.Kom., Sulindawaty M.Kom. 2013."Penerapan Associaton Rule dengan Algoritma Apriori Pada Proses Pengelompokan Barang di Perusahaan Retail”. STMIK-Triguna Dharma. Medan Sumatra Utara, Indonesia.

[8] McQueen J. 1967. Some Methods for Classification and analysis of multivariate observations, In Proc, of $5^{\text {th }}$ Berkeley Symp Mathematics, statistics and probability, pp.281-296. Univercity of California Los Angeles.

[9] Diahpangastuti, Nucifera. 2012. Sistem Rekomendasi Bidang Minat Mahasiswa Menggunakan Metode Association Rule dan algoritma Apriori. Teknik Informatika FTIF-ITS.

[10] Erwin. 2009. "Analisis Market Basket Dengan Algoritma Apriori dan FP-Growth". Program studi Teknik Informatika, Fakultas Ilmu Komputer, Universitas Sriwijaya. Vol. 4 No. 2 (Juli 2009) Jurnal Generic.

[11] Thangsupachai, Noppol., dkk. 2011. Clustering Large Datasets with Apriori-Based Algorithm and Concurrent Processing. Proceedings of International MultiConference of Engineers and Computer Scientists 2011 Vol I, IMECS 2011, March 16-18, 2011. Hong Kong.

[12] Larose, T. Daniel. 2005. Discovering Knowledge In Data An Introduction to Data Mining. Central Connecticut State University. 